\title{
Weaning stress is affected by nutrition and weaning methods
}

\author{
J. L. Holland, D. S. Kronfeld, R. M. Hoffman, K. M. Greiwe-Crandell, T. L. Boyd, W. L. Cooper and P. A. Harris* \\ Virginia Tech M.A.R.E. Center, Middleburg, USA \\ *Waltham Centre for Pet Nutrition, Melton Mowbray, England
}

\begin{abstract}
Summary
The objectives of these studies were to compare effects of diet and weaning method on stress responses in Thoroughbreds raised on pasture. Ethograms showed that foals weaned abruptly were more stressed than foals weaned gradually, and foals supplemented with the fatand-fiber diet were less stressed. Cortisol levels in foals supplemented with a corn-based diet were higher before and after weaning compared to foals fed a fat-and-fiber supplement. These studies indicate that foals weaned gradually were less stressed and that diet may affect a foals' ability to handle the stress of weaning.
\end{abstract}

keywords: $\quad$ weaning, stress, ascorbate, cortisol, behavior

\begin{abstract}
Streß beim Absetzen wird durch Fütterung und Absetztechnik beeinflußt
In der vorliegenden Untersuchung sollte bei Vollblutfohlen der Einfluß der Ernährung und der Technik des Absetzens auf die Streßbelastung bei Weidehaltung verglichen werden. Ethogramme zeigten, daß abrupt abgesetzte Fohlen stärker gestreßt wurden als Fohlen mit protrahiertem Absetzen und daß ein fett- und rohfaserreiches Ergänzungsfutter den Streß zu mindern vermochte. Die Kortisolspiegel waren bei Fohlen, die ein maisreiches Ergänzungsfutter erhielten, vor und nach dem Absetzen höher als bei Fohlen mit fett- und rohfaserreichem Ergänzungsfutter. Diese Untersuchungen zeigen, daß protrahiertes Absetzen die Fohlen weniger streßte und daß das Futter die Fähigkeit der Fohlen, die Belastungen zu bewältigen, beeinflussen kann.
\end{abstract}

Schlüsselwörter: Absetzen, Streß, Ascorbat, Kortisol, Verhalten

\section{Introduction}

Stress physiology and behavior are used to evaluate animal welfare (Fraser et al. 1975; Ewbank 1985). A central feature of stress is the release of adrenocorticotrophic hormone $(\mathrm{ACTH})$ from the anterior pituitary, which is the primary regulator of cortisol secretion by the adrenal glands. Changes in plasma cortisol concentration have been shown to be a sensitive index of adrenocortical response (James et al. 1970). The pituitaryadrenal response is stimulated typically by emotional perturbations such as uncertainty or social dislocation (Dantzer and Mormêde 1985; Hart 1985).

The stress of social dislocation is exemplified when foals are weaned. Foals weaned by gradual as opposed to abrupt separation methods exhibited fewer behavioral signs of stress (McCall et al. 1985; McCall et al. 1987). Post-weaning plasma cortisol concentrations were elevated in both mares and foals (Malinowski et al. 1990). Foals weaned into stalls singly had less stress than foals weaned into stalls in pairs (Hoffman et al. 1995).

Serum ascorbate is depleted in horses with severe infections, long bone fractures and over-training (Jaeschke and Keller 1978; Jaeschke 1984). Plasma ascorbate concentration has also been shown to be low in weaned foals (Hoffman et al. 1995). These findings suggest that blood ascorbate concentrations may serve as an indicator of stress in horses.

The objectives of the present studies were to compare behavioral and hormonal responses of foals subjected to abrupt or gradual weaning and to different diets.

\section{Materials and methods}

Two pasture weaning experiments used foals between the ages of 5 and 7 months at time of weaning. All foals had been handled monthly from birth.

Experiment 1: Twenty foals born in 1992 were kept on pasture with their dams. The mares were fed one of two diets, an ail forage $(\mathrm{PH})$ diet, or a forage and pelleted concentrate $(\mathrm{PHC})$ diet. Foals had access to the same diets as their dams. Prior to weaning, mare/foal pairs were divided into two groups (5 mare/foal pairs) per diet and placed on separate pastures. One group on each diet were weaned abruptly (all mares removed at the same time) while the other group was weaned gradually (1 to 2 mares removed every 2 days).

An ACTH response test was conducted 72 hours after weaning. A jugular blood sample was taken prior to an ACTH challenge of $1 \mathrm{IU} / \mathrm{kg}$ BW repository corticotrophin (H.P. Acthar Gel, Rorer Pharmaceuticals, Fort Washington, PA) injected IM (Plumb 1991). A second blood sample was taken 5 hours post-injection. All samples were analyzed for serum cortisol using a radioimmunoassay procedure (Coat-A-Count Cortisol, Diagnostic Products, Los Angeles, CA).

An ethogram of each foal's activity was recorded for 1 hour the day of weaning and the next 2 days. Activities recorded were frequency of vocalizations, and time spent walking, trotting, cantering, standing and grazing. Other behaviors recorded include play behavior, aggressive behavior, rearing, kicking, tail chewing, epilemetic and et-epilemetic behaviors. 
Tab. 1: Typical behavioral and physical signs of stress observed in foals on pasture.

Typische Verhaltensmuster bei Streß bei Weidefohlen

\begin{tabular}{|l|l|l|}
\hline Eustress & Mild distress & Severe distress \\
\hline Whinnies occasionally & Whinnies frequently & Silent \\
\hline Alert, attentive & Inattentive, distracted & Depressed, unresponsive \\
\hline Stands well & Paws, weaves, shakes head, chews fence & Stands with head lowered \\
\hline Walks & Trots or canters & Immobile \\
\hline Epilemetic behavior & Agonistic behavior & Apathetic \\
\hline -plays & -biting, kicking, fighting & -no response to others if they nurse, bite, etc. \\
\hline -gives care and attention & & \\
\hline Et-epilemetic behavior & Avoids company & Ignores company \\
\hline- plays & & -does not run, play, etc. when others do \\
\hline- seeks company & & \\
\hline,- nurses“ other foals & & -reluctant to follow when whole herd moves \\
\hline Eats well & Eats poorly & No interest in eating \\
\hline$->50 \%$ of time & $-10-40 \%$ of time & -<10\% of time \\
\hline
\end{tabular}

Behavioral scores were assigned to each foal (Tab. 1) using a rating scale used by Hoffman et al. (1995). This method gives scores (1 to 10) based on the number of stress signs, three or more signs of severe distress scoring 1 , no stress signs scoring 10.

Experiment 2: Twenty-four foals born in 1994 were kept on pastures with their dams. Ten had access to a supplement high in starch and sugar (SS), the other ten to a supplement high in fat and fiber (FF). The remaining four foals were maintained on a pelleted (PEL) concentrate and pasture. All foals were weaned using a gradual method, except for the PEL foals which were not weaned. Within each dietary group 3 mares were removed at once every 3 days. The tenth mare remained with the foals for 2 weeks as a "babysitter".

Jugular blood samples were taken from all of the foals prior to weaning and analyzed for plasma ascorbate concentration and serum cortisol concentration. The foals on the pelleted concentrate were used for the determination of preweaning ACTH response values.

Jugular blood samples were taken from weaned foals 48 hours post weaning and analyzed for plasma ascorbate by HPLC (Schiiep et al. 1987). An ACTH response test was conducted 48 hours after weaning.

Ethograms of weaned foals were recorded the day of weaning and for 2 days post weaning, as in Experiment 1.

\section{Results}

Experiment 1: Pre-ACTH serum cortisols were lower in colts $(6.0 \pm .44 \mathrm{ug} / \mathrm{dL})$ than in fillies $(7.0 \pm .33 \mathrm{ug} / \mathrm{dL})(P=.068)$ and colts had a larger change after being challenged with exogenous ACTH $(6.8 \pm .48 \mathrm{ug} / \mathrm{dL}$ for colts versus $5.6 \pm .42 \mathrm{ug} / \mathrm{dL}$ for fillies) $(P=.060)$ but there was no difference between diet or treatment groups. There were no differences in serum cortisol level between sex, diet or treatment groups post-ACTH.
All foals had more vocalizations on day 1 than on day 3 ( $P<$ .0001) (Fig. 1). Foals in the gradually weaned group were more vocal $(30 \pm 5)$ the day of weaning $(P=.010)$ than foals weaned abruptly $(21 \pm 1)$. All foals walked and cantered more on day 1 than day $3(P<.0001)$ and abruptly weaned foals walked more $(7$ \pm .2 minutes) on day $1(P<.0001)$ than gradually weaned foals $(5$ \pm 1 minutes). Abruptly weaned foals walked more on day 2 ( $P$ $<$.0001) than gradually weaned foals and PHC foals walked more on all days $(\mathrm{P}=.0004)$ than $\mathrm{PH}$ foals. Abruptly weaned foals cantered more on day 1 ( 4 minutes) $(P=.0002)$ than gradually weaned foals (2 minutes). All foals stood and grazed less on day $1(P<.0001)$ than on day 3 (Fig. 1), gradually weaned foals grazed more than abruptly weaned foals $(P=.0002)$, and $\mathrm{PH}$ foals grazed more $(\mathrm{P}=.0003)$ than $\mathrm{PHC}$ foals. Behavior scores were lower on day 1 than day $3(P<.0001)$ and were lower initially for foals weaned abruptly $(P<.0001)$ (Tab. 2).

Experiment 2: Preweaning serum cortisols differed between diet groups $(P=.003)$ with foals consuming the FF diet being lower $(5.3 \pm .59 \mathrm{ug} / \mathrm{dL})$ than either the SS $(6.6 \pm .44 \mathrm{ug} / \mathrm{dL})$ or PEL (6.6 $\pm 1.10 \mathrm{ug} / \mathrm{dL}$ ) foals (Fig. 2). There were no differences in the pre-ACTH or post-ACTH serum cortisols due to sex, diet or treatment. Foals that were on the PEL diet and were not weaned had a smaller change in serum cortisol (5.9 \pm .39 $\mathrm{ug} / \mathrm{dL}$ ) after $\mathrm{ACTH}$ challenge than the foals that were weaned $(6.8 \pm .30 \mathrm{ug} / \mathrm{dL})(\mathrm{P}=.014)$.

Preweaning plasma ascorbates were slightly lower in fillies $(6.5$ $\pm .34 \mathrm{mg} / \mathrm{mL})$ than in colts $(6.9 \pm .33 \mathrm{mg} / \mathrm{mL})$. There were no differences due to diet. There were differences due to treatment in postweaning plasma ascorbates. The last foals to be weaned had higher plasma ascorbate values $(7.7 \pm .63$ $\mathrm{mg} / \mathrm{mL}$ ) than the foals of the first and second groups (6.8 \pm $.41 \mathrm{mg} / \mathrm{mL}$ ). There were no differences due to sex or diet. There were differences in the relative change in plasma ascorbate from pre- to post weaning samples. Foals weaned in the third group had consistently higher difference $(1.2 \pm .28$ 


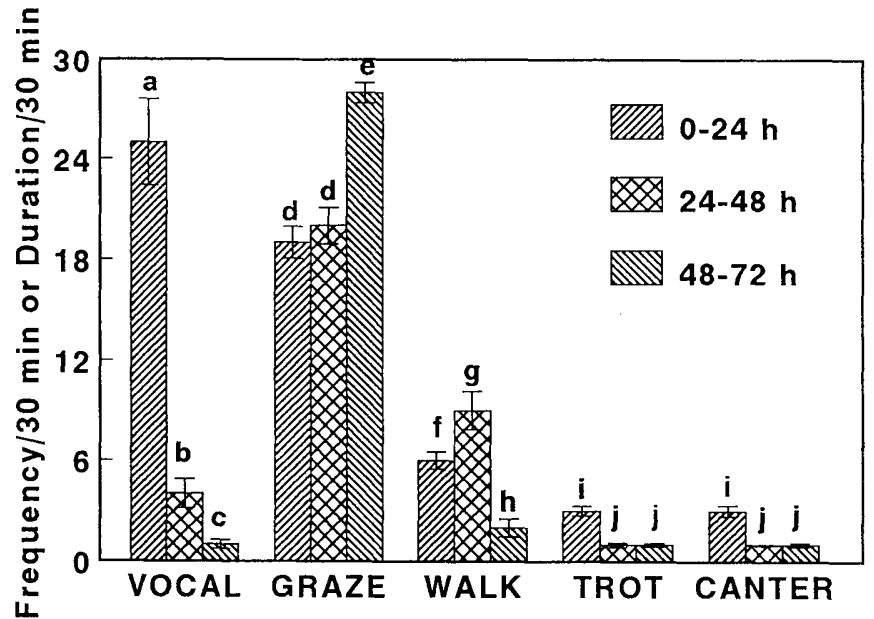

Fig. 1: Effects of weaning on foal behavior. Differences due to day after weaning. Means lacking a common superscript differ.

Einfluß des Absetzens auf das Fohlenverhalten, Unterschiede zwischen den Tagen nach dem Absetzen

$$
\begin{array}{ll}
\text { a.b } P<.0001 & \text { f.g } P=.002 \\
\text { b.c } P<.001 & \text { g.h } P<.001 \\
\text { d.e } P<.0001 & \text { i.j } P<.0001
\end{array}
$$

$\mathrm{mg} / \mathrm{mL})$ than foals weaned in the first two groups $(.5 \pm .451$ $\mathrm{mg} / \mathrm{mL})(\mathrm{P}=.007)$.

As in experiment 1 , all foals were more vocal on day 1 postweaning than on day $2(P=.0030)$ and day $3(P=.090)$. Foals on the FF diet were more vocal $(35 \pm 6)$ on the day of weaning $(P=.020)$ than foals fed SS $(20 \pm 5)$. All foals walked more on day 1 than day $3(P=.070)$. Foals weaned in the second and third groups trotted more $(1.5 \pm .5$ minutes $)$ than foals weaned first $(P=.001)$ and these foals trotted more on day 1 than day $3(\mathrm{P}=.003)$. Foals weaned in the second and third groups also cantered more $(P=.0009)$ than the foals weaned first and they cantered more on day $1(P<.0001)$ than day 3 . The SS foals stood more on day $1(P<.0001)$ than day 3 and grazed more

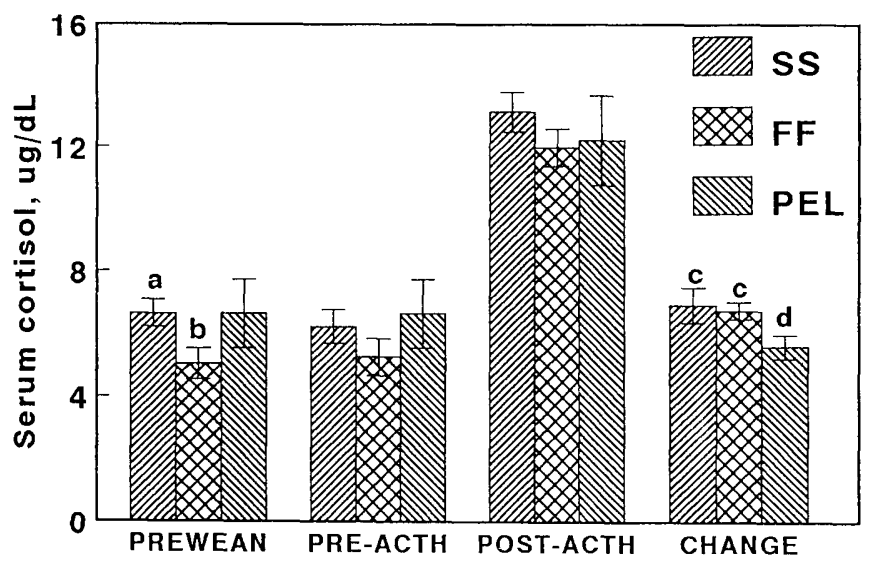

Fig. 2: Changes in serum cortisol when challenged with ACTH. The PEL group was not weaned. The SS and FF groups were challenged 48 hours after weaning. SS refers to foals fed the starch-and sugar concentrate, FF to foals fed the fat-and-fiber concentrate and PEL to foals fed the pelleted concentrate. Means lacking a common superscript differ.

Veränderungen der Serumkortisolspiegel nach Stimulation mit ACTH

$$
\mathrm{a} . \mathrm{bP}=.003 \quad \mathrm{c}, \mathrm{d} \mathrm{P}=.014
$$

on day $3(P=.002)$ than day 1 . The FF foals that were weaned in the second and third groups grazed more $(39 \pm 4.156 \mathrm{mi}-$ nutes) on day $1(P=.015)$ than the foals weaned in the first group (18 \pm 2.646 minutes). As in experiment 1 , foals received lower behavior scores on the first day after weaning $(P<.0001)$. Foals weaned first had a higher behavior score on day 1 than foals weaned in the second and third groups $(P=.0015)(T a b .2)$.

\section{Discussion}

ACTH response: Pre-ACTH serum cortisols were lower in colts than in fillies (Experiment 1) as observed in other mammals (Gray 1971). In Experiment 2, foals consuming the FF

Tab. 2: Behavior scores given to foals the first three days after weaning. Scores based on Tab. 1.

Bewertungsnoten zum Verhalten von Fohlen in den ersten 3 Tagen nach dem Absetzen. Bewertungsnoten s. Tab.1

\begin{tabular}{|l|l|l|l|l|l|}
\hline & & & DAY 1 & DAY 2 & DAY 3 \\
\hline Experiment 1 & Treatment & GRAD $(n=10)$ & $5.1 \pm .23^{\mathrm{a}, \mathrm{e}}$ & $7.4 \pm .48^{\mathrm{b}}$ & $8.5 \pm .34^{\mathrm{c}}$ \\
\hline & & AAO $(\mathrm{n}=10)$ & $4.0 \pm 0^{\mathrm{a}, \mathrm{f}}$ & $7.3 \pm .15^{\mathrm{b}}$ & $8.5 \pm .17^{\mathrm{d}}$ \\
\hline & Diet & PH $(\mathrm{n}=10)$ & $4.4 \pm .22^{\mathrm{a}}$ & $7.3 \pm .34^{\mathrm{b}}$ & $9.0 \pm 0^{\mathrm{d}}$ \\
\hline & & PHC $(\mathrm{n}=10)$ & $4.7 \pm .26^{\mathrm{a}}$ & $7.4 \pm .37^{\mathrm{b}}$ & $8.0 \pm .30^{\mathrm{h}}$ \\
\hline & & TRT 1 $(\mathrm{n}=6)$ & $6.5 \pm .34^{\mathrm{a}, \mathrm{e}}$ & $7.8 \pm .31^{\mathrm{b}}$ & $8.5 \pm .22^{\mathrm{c}}$ \\
\hline & Treatment & TRT 2 $(\mathrm{n}=6)$ & $4.8 \pm .31^{\mathrm{a}, \mathrm{f}}$ & $7.2 \pm .31^{\mathrm{b}}$ & $8.8 \pm .17^{\mathrm{d}}$ \\
\hline & & TRT 3 $(\mathrm{n}=6)$ & $5.3 \pm .21^{\mathrm{a}, \mathrm{f}}$ & $8.2 \pm .31^{\mathrm{b}}$ & $8.2 \pm .48^{\mathrm{b}}$ \\
\hline & & SS $(\mathrm{n}=9)$ & $5.8 \pm .40^{\mathrm{a}}$ & $7.9 \pm .35^{\mathrm{b}}$ & $8.3 \pm .33^{\mathrm{b}}$ \\
\hline & & FF $(n=9)$ & $5.3 \pm .24^{\mathrm{a}}$ & $7.6 \pm .18+^{\mathrm{b}}$ & $8.7 \pm .18^{\mathrm{d}}$ \\
\hline
\end{tabular}

Scores with different letters are significantly different.

Differences between days: $\quad \mathrm{a}, \mathrm{bP}<.0001, \mathrm{~b}, \mathrm{c} \mathrm{P}=.015, \mathrm{~b}, \mathrm{dP}<.001, \mathrm{~b}, \mathrm{hP}=.09$

Differences between treatments: $\quad$ e.f $P<.0015$ 
diet had lower serum cortisol levels before weaning than those fed the SS diet. However, there were no differences in serum cortisol responses to an ACTH challenge due to weaning method, diet or treatment. Some previous studies have reported no significant differences in plasma cortisol concentration due to weaning method (Houpt et al. 1984; Malinowski et al. 1990). In other previous studies, foals weaned abruptly from their dams had higher adrenal response to $\mathrm{ACTH}$ challenge and higher pre-ACTH and post-ACTH plasma cortisol concentrations (MCCall et al. 1987). Also, diet and weaning method have affected ACTH response values (Hoffman et al. 1995); foals fed a concentrate providing minerals deficient in pasture and foals weaned singly into stalls had higher responses to $\mathrm{ACTH}$ challenge. The reason our foals may not have shown expected stress responses to weaning may be related to their being kept on familiar pastures instead of removed to either stalls or to different pastures.

Plasma ascorbate: Plasma ascorbate values recorded in Experiment 2 were double those previously reported in stall-weaned foals (Hoffman et al. 1995). Foals in the stall weaning study were not accustomed to being housed in stalls, and this could have led to their being more stressed initially, explaining the tower plasma ascorbate values.

In Experiment 2, the foals that were weaned last had higher postweaning plasma ascorbates and had a larger difference from pre-weaning to postweaning levels than the other foals. This may indicate that these foals were more accustomed to the removal of mares than the other foals. Reported values were similar to those reported for normal adult horses, 5.9 to 7.3 $\mathrm{mg} / \mathrm{mL}$ (Errington et al. 1942; Jaeschke 1984) but indicate that plasma ascorbate levels tend to be somewhat higher in young horses as has been suggested by others (Jaeschke 1984).

Behavioral responses: All foals in both experiments showed more behavioral signs of stress the first day of weaning than by the third day after weaning. In general, foals were more active (walking trotting, and cantering) and more vocal on day 1 than day 3. By the third day after weaning, most foals spent the majority of their time grazing.

Gradually weaned foals were more vocal in Experiment 1 but abruptly weaned foals were more active than gradually weaned foals, and therefore appeared to be more stressed. These results are similar to previously reported studies where abrupt weaning methods were found to be more stressful than partial separation methods (McCall et al. 1985; McCall et al. 1987). Foals in Experiment 1 which received a concentrate supplement $(\mathrm{PHC})$ walked more on all days than foals not receiving a supplement. This differs from previous studies (MCCall et al. 1985) and may indicate that these foals were more stressed at weaning. Foals in the $\mathrm{PH}$ group grazed more on all days than PHC foals but may be more an indication of dietary need than stress response to weaning.

In experiment 2, foals weaned in the second and third groups who were fed FF grazed more which suggests they were less stressed. Foals weaned first in both dietary groups may have been less stressed because of the larger number of mares that were left in the group, and the separation from their dams may not have been as traumatic.
Foals received lower behavior scores the first day after weaning. Foals weaned by gradual methods received higher scores than foals weaned abruptly. These behavior scores were higher than those previously reported (Hoffman et al. 1995) but again, this may be due to leaving the foals on pastures where they had been raised instead of placing them in unfamiliar surroundings.

In conclusion, foals weaned in groups where all mares were removed at once were more stressed than groups where a few mares were removed at a time. Foals adapted to weaning better when left on pastures than when weaned into stalls. Diet energy source may influence the ability of foals to cope with weaning, fat-and fiber possibly having an advantage over starch and sugar.

\section{References}

Dantzer, $R$. and Mormêde, P. (1985): Stress in domestic animals: a psychoneuroendocrine approach. In: G.P. Mober (Ed.) Animal Stress. p. 81. Am. Phys. Soc., Bethesda, MD.

Errington, B. J., Hodgkiss, W. S. and Jayne, E. P. (1942): Ascorbic acid in certain body fluids of horses. Amer. J. Vet. Res. 3, 242

Ewbank, R. (1985): Behavioral responses to stress in farm animals. In: G.P. Moberg (Ed.)Animal Stress. p. 71. Am. Phys. Soc., Bethesda, MD.

Fraser, D., Ritchie, J. S. D. and Fraser, A. F. (1975): The term "stress" in a veterinary context. Br. Vet. J. 131, 653

Gray, J. A. (1971): Sex differences in emotional behavior in mammals including man: Endocrine basis. Acta Psychol. 35, 29

Hart, B. L. (1985): The Behavior of Domestic Animals. W.H. Freeman and Co., New York.

Hoffman, R. M., Kronfeld, D. S., Holland, J. L. and Greiwe-Crandell, K. M. (1995): Preweaning diet and stall weaning method influences on stress response in foals. J. Anim. Sci. 73, 2922

Houpt, K. A., Hintz, H. F. and Butler, W. R. (1984): A preliminary study of two methods of weaning foals. Appl. Anim. Behav. Sci. 12, 177

Jaeschke, G. (1984): Influence of ascorbic acid on physical development and performance of racehorses. In: 1. Wegger, F.J. Tagwerker and J. Moustgaard (Eds.) Proc. Workshop on Ascorbic Acid in Domestic Animals p.153. Scan. Assoc. Agr. Sci. and Royal Dan. Agr. Soc.

Jaeschke, G. und Keller, H. (1978): Beitrag zum Ascorbinsäurestatus des Pferdes. 2. Mitteilung: Klinische Aspekte und Mangelsituationen. Berl. Münch. Tierärztl. Wschr. 91, 375

James, V. H. T., Horner, M. W., Moss, M. S. and Rippon, A. E. (1970): Adrenocortical function in the horse. Endocrinology. 48, 319

Malinowski, K., Hallquist, N. A., Halyar, L., Sherman, A. R. and Scanes, C. G. (1990): Effect of different separation protocols between mares and foals on plasma cortisol and cell-mediated immune response. J. Eq. Vet. Sci. 10, 363

McCall, C. A., Potter, G. D. and Kreider, J. L. (1985): Locomoter, vocal and other behavioral responses to varying methods of weaning foals. App. Anim. Behav. Sci. 14, 27

McCall, C. A., Potter, C. A., Kreider, J. L. and Jenkins, W. L. (1987): Physiological responses in foals weaned by abrupt or gradual methods. J. Eq. Vet. Sci. 7, 368

Plumb, D. C. (1991): Veterinary Drug Handbook. Pharma Vet Publishing: White Bear Lake, Minnesota.

Schiiep, W., Vuilleumier, J. P., Gysel, D. and Hess, D. (1987): Determination of ascorbic acid in body fluids, tissues and feedstuffs. Laboratory Notebook 15229, p. 45. Dept. Vitamin Nutritional Research, Hoffmann-La Roche \& Co., Basle, Switzerland.

Supported in part by Mr. Paul Mellon, Upperville, Virginia, and the Waltham Centre for Equine Nutrition and Care, Verden, Germany.

Janice L. Holland

Virginia Tech M.A.R.E. Center

5527 Sullivans Mill Road

Middleburg, VA 22117-9701

USA 